\title{
Limites e abusos de interpretação do Supremo Tribunal Federal no caso ADPF 54 (aborto de anencéfalos): análise crítica a partir de Habermas e Streck
}

\author{
Limits and abuses of interpretation of the \\ Federal Supreme Court case ADPF 54 (abortion \\ anencephalic): critical analysis from Habermas and \\ Streck
}

\author{
Janaína Reckziegel ${ }^{\star}$ \\ Riva Sobrado de Freitas ${ }^{*}$
}

\section{Resumo}

O presente artigo tem por objetivo discutir a decisão proferida pelo Supremo Tribunal Federal frente à possibilidade de prática de interrupção da gestação em casos de fetos anencéfalos, reportando-se a contornos éticos e jurídicos. Diante da omissão legislativa sobre o assunto, faz-se necessário recorrer ao Poder Judiciário para que decida sobre esse problema. O artigo buscará uma resposta adequada frente à Constituição Federal, através de mecanismos democráticos, possibilitando a participação popular representativa para legitimar o poder e as decisões pela referida corte, acreditando-se que seja a melhor resposta, e não uma escolha ética individualista, que enfraqueceria

Professora e Pesquisadora da Universidade do Oeste de Santa Catarina. Doutora em Direitos Fundamentais e Novos Direitos pela Universidade Estácio de Sá - RJ. Mestre em Direito Público. Especialista em "Mercado de trabalho e exercício do magistério em preparação para a Magistratura" e em "Educação e docência no ensino superior". Graduada em Ciências Jurídicas e Sociais pela Universidade do Oeste de Santa Catarina. Advogada e Professora Universitária. Chapecó - RS - Brasil. E-mail: janainar@desbrava.com.br.

** Professora de Direitos Fundamentais da Universidade do Oeste de Santa Catariana; Professora Adjunta - Doutora aposentada da Universidade Estadual Paulista "Júlio de Mesquita Filho"; Graduada em Direito pela Universidade de São Paulo; Mestre e Doutora pela Pontifícia Universidade Católica de São Paulo; Pós-doutora em Direitos Humanos pela Universidade de Coimbra, Portugal; Investigadora do Programa de Pós-graduação em Direito da Universidade do Oeste de Santa Catarina. Chapecó - RS - Brasil. E-mail: rivafreit@ig.com.br. 
a cidadania e a própria democracia, acabando por desvirtuar o processo e a vontade do Poder Legislativo, o qual deveria representar a vontade do povo, sendo eleito para demandar sobre essas questões políticas e efetivar direitos, evitando decisões arbitrárias e discricionárias.

Palavras-chave: Ativismo judicial. Relações privadas parentais. Interrupção de gestação. Fetos anencéfalos. Construção da resposta correta.

\section{Abstract}

This article aims to discuss the decision of the Supreme facing the possibility of practicing interruption of pregnancy in cases of anencephalic fetuses Federal Court, referring to ethical and legal boundaries. Given the legislative omission on the subject, it is necessary to rely on the judiciary to decide on the issue. The article will seek an appropriate response against the Federal Constitution through democratic mechanisms, enabling the representative citizen participation to legitimize power and decisions by that court, believing himself to be the best answer, not an individualistic ethical choice, which would weaken the citizenship and democracy itself, eventually undermine the process and the will of the Legislature, which should represent the will of the people being elected to sue on these policy issues to enforce rights avoiding arbitrary and discretionary decisions.

Keywords: Jucicial activism. Private parental relations. Interruption of pregnancy. Anencéfalos fetus. Construction of correct.

\section{Introdução}

Com a evolução da sociedade, ocorreram mudanças sociais em vários aspectos: ideologias, valores, crenças, culturas e estudos científicos, como reprodução humana assistida, manipulação genética, intervenções científicas em embriões humanos, aborto de anencéfalos, entre outros, os quais trazem complexos desafios que não são fáceis de serem resolvidos e necessitam de soluções. 
Nota-se que há uma lacuna no Código Penal quando se trata de aborto no caso da gestação de fetos anencéfalos, tema que permanece, portanto, à margem de um tratamento legislativo específico, o que hoje não se encontra, em razão de a ausência legislativa estar adentrando no Judiciário através do ativismo judicial, demonstrando a importância teórico-social da discussão.

Procurar-se-á trazer à baila para a reflexão a questão do papel da jurisdição constitucional na tomada de decisões políticas e sociais complexas e as suas consequências dentro da perspectiva do Estado Democrático de Direito, em especial, utilizando como parâmetros de debate as Teorias de Jürgen Habermas e de Lenio Streck, a decisão tomada pelo Supremo Tribunal Federal sobre a interrupção de gravidez em caso de feto anencéfalo.

O Supremo Tribunal Federal foi impulsionado, através da Arguição de Descumprimento de Preceito Fundamental (ADPF) $\mathrm{n}^{\circ} 54$, a se manifestar acerca dos artigos 124, 126 e 128, incisos I e II do Código Penal, e acerca do direito à vida, à liberdade, à proteção da autonomia da vontade, à saúde e à dignidade da pessoa humana, motivos pelos quais foi interposta a declaração de inconstitucionalidade, com eficácia para todos e efeito vinculante dos artigos supra do Código Penal, que impede a antecipação terapêutica do parto em casos de gravidez de feto anencéfalo.

O assunto será abordado em três partes: em um primeiro momento, faz-se o resgate histórico e jurídico reportando-se a discricionariedade das decisões judiciais, pois é indispensável à introdução do tema de pesquisa. Em seguida, passa-se a análise da teoria procedimentalista de Jürgen Habermas para buscar o afastamento da discricionariedade do Poder Judiciário na solução de conflitos sociais, utilizando-se da democracia participativa e confrontando-a com a decisão do Supremo Tribunal Federal, especificamente sobre a interrupção de gravidez em caso de feto anencéfalo, sem que a gestante seja criminalizada por tal ato, objetivando verificar se houve uma jurisdição constitucional aberta e democrática. 
Por fim, buscou-se estudar a Crítica Hermenêutica do Direito ou a Nova Crítica do Direito, construída por Dr. Lenio Streck, para fazer um contraponto com a solução estabelecida pelo Supremo Tribunal Federal na ADPF $n^{\circ} 54$, a fim de verificar se a resposta dada como solução alcançou a resposta correta frente à Constituição Federal.

\section{Contornos éticos, jurídicos e a discricionariedade das decisões judiciais}

O reconhecimento do indivíduo como ser autônomo e dotado de dignidade, trazido pela modernidade, suplanta a noção que outrora o reduzia a mero objeto a partir da própria concepção de direitos humanos que começava a se estabelecer, conferindo-lhe respaldo social e jurídico. A superação dos chamados "determinismos naturais" ou mesmo das explicações de cunho divino, típicas da fase medieval, cedeu espaço à racionalidade e à ciência, oportunizando, com o transcorrer dos tempos, um progresso significativo também na área médica, por meio da descoberta de técnicas curativas ou medicamentos importantes para a saúde humana. $\mathrm{O}$ crescente poder de intervenção e controle sobre a dinâmica, quer natural, quer social, que se perfez pela consciência de liberdade e autonomia assumidas nesse novo cenário cultural, acabou por despertar no ser humano, a contrario sensu, uma perigosa medida de suas potencialidades, externando-se no emprego de métodos imprudentes e lesivos no exercício da medicina (JUNGES, 2006).

Tem-se, no século XX, o período histórico que se notabiliza pela proliferação de legislações nacionais e tratados internacionais nas áreas civis, políticas, econômicas, culturais, entre outras (BARRETO, 2003), que buscaram positivar e ressaltar a necessidade do respeito aos direitos individuais (HOBSBAWM, 2006). Contudo, foi também o século em que, paradoxalmente, a humanidade sofreu as mais horrendas violações, como as experiências médicas realizadas em seres humanos na Segunda Guerra Mundial (BOGOD, 2004). 
Voltada à discussão interdisciplinar e à busca de diretrizes para a execução de experimentos científicos, a Bioética ${ }^{1}$ vem a irradiar o Direito, estendendo também a ele a preocupação ética, que acaba por se traduzir também na imperiosa necessidade de propositura de limites jurídicos às técnicas biomédicas, e a sua regulamentação em ordenamentos internos ou postulados internacionais, a exemplo da Declaração dos Direitos do Homem (1948) e da Declaração de Helsinque. Em verdade, a complexidade e relevância do tema acabaram por suscitar um novo campo do Direito, específico para o estudo e normatização das questões bioéticas sob a denominação de Biodireito (MÖLLER, 2009).

As demandas sociais e as complexidades dos problemas aumentaram demasiadamente, alcançando um grau de detalhamento e especialização que o legislador não conseguiu prever e, tampouco, acompanhar e dar uma resposta imediata e adequada. Além disso, a positivação do Direito, a qual tem por princípio fundar-se em si mesmo, independentemente de qualquer tipo de valoração ética, afasta-se da discussão sobre as bases racionais que possam dar sustentação às normas positivadas, transformando o Direito em uma ciência que corre o risco de girar em torno de um vazio, perdendo completamente o sentido de sua ação (ZAGREBELSKY, 2005).

O Poder Legislativo tem como missão encontrar soluções para os problemas apresentados através da criação de leis, observando que esse sistema formalista do Direito ingressou na época contemporânea, com a contribuição doutrinária do jurista Hans Kelsen, em sua obra Teoria Pura do Direito, na qual procurou demonstrar a necessidade de purificação do método jurídico, sob o argumento de que as normas positivadas eram obrigatórias, não porque tinham fundamento moral ou religioso, mas porque eram legitimadas por uma norma jurídica superior (Grundnorm), que tinha um fim em si, pois legitimava a si e a todas

O termo Bioética (Bio=Ethik) foi empregado pela primeira vez no ano de 1927, em artigo de Fritz Jahr publicado no periódico alemão Kosmos, oportunidade em que é tratada como "o reconhecimento de obrigações éticas não apenas com relação ao ser humano, mas para com todos os seres vivos" (GOLDIM, 2009, p. 55). 
as demais (KELSEN, 1976), criando o "sujeito de direitos", que seria reconhecido pelo sistema jurídico como portador de direitos e deveres, ficando obrigado ao cumprimento de mandamentos legais (HABERMAS, 2003b).

A partir da perda do sentido ético do Direito (LARENZ, 2005), ocorreram vários problemas sociais. Entre eles, pode-se citar a dignidade da pessoa humana, que ficou para segundo plano no processo de legalização do "sujeito de direitos". Dessa forma, Gillisen (2003) afirma que é permitido ao indivíduo fazer tudo o que a lei não proíbe, e ao Estado desonerou-se a obrigação de proteger valores não disciplinados pelo ordenamento jurídico.

Com a ocorrência da evolução social e científica, o legislador não conseguiu acompanhá-la, devido à sua complexidade, impossibilitando-o de responder correta e adequadamente aos casos concretos. Contudo, observa-se que a positivação do Direito (fundar-se em si mesmo) não depende de valores éticos, mas, afastando-os, corre o risco de criar uma ciência fria, não preocupada com os valores e a moral adotada por uma sociedade, como foi o caso da Alemanha nazista (ZAGREBELSKY, 2005).

Frente à falta de um fundamento, por parte do legislador, sobre a possibilidade do aborto em gestação de fetos anencéfalos, o conflito social "bateu na porta" do Poder Judiciários, especificamente do Supremo Tribunal Federal.

Na qualidade de "guardião" da Constituição Federal, o Supremo Tribunal Federal tem como uma de suas atribuições verificar a (in) constitucionalidade da legislação infraconstitucional, podendo o Legislativo limitar-se a efetuar uma interpretação restritiva dos direitos constitucionalmente postos em questão, adotando uma postura jurisdicional e, com isso, não responder determinados pontos de tensão social; ou então optar por uma interpretação expansiva, dando uma resposta para o problema que os órgãos democraticamente eleitos não conseguiram (QUEIROS, 2008). Mas, nesse sentido, o Poder Judiciário 
poderá incorrer em decisões discricionárias se não utilizar fundamentos e bases teóricas consistentes para responder a cada situação concreta.

Encontra-se enfraquecido o Poder Legislativo, devido à complexidade dos problemas socais, pois não está conseguindo soluções políticas capazes de se sustentarem diante da ausência de fundamentação racional que garanta sua aceitação, recolocando os conflitos para o Poder Judiciário, que acaba por ultrapassar sua atuação jurisdicional na busca de soluções sobre os temas que lhe são apresentados.

Como marco histórico, cita-se a Constituição Federal de 1988, quando o Poder Constituinte Originário, para conseguir assegurar a tutela constitucional e garantir os direitos fundamentais, instrumentalizou o Poder Judiciário com ações ${ }^{2}$ para ter controle sobre as políticas públicas.

Para atingir os fins previstos na Constituição Federal, o Poder Judiciário acaba tomando decisões muitas vezes imprevisíveis e confronta-se com o Executivo ou o Legislativo, corrigindo ou ajustando suas ações ou omissões (COSTA, 2000).

Percebe-se que o real papel da jurisdição constitucional vai além de controlar a proteção dos seres humanos contra os abusos estatais; procura-se oportunizar uma maior eficácia aos direitos fundamentais através da interpretação e integração, cabendo aos magistrados efetuarem-nas na lei, conforme os ditames constitucionais (SARLET, 2005).

Procedimentalistas como Habermas, entre outros, censuram essa prática, pois afirmam que ao Judiciário não cabe esse tipo de interferência, pois questões polêmicas e complexas com conteúdos morais e éticos deveriam ser resolvidas por debate nacional, verificando

Ações como ação popular, mandado de injunção, ação civil pública, controle da constitucionalidade etc. 
a opinião pública a respeito (GESTA LEAL, 2006); caso contrário, impossibilitaria a participação democrática da população (HABERMAS, 2003a).

Streck (2006) critica a objeção apresentada pelos procedimentalistas e defende que não se pretende defender a substituição da discricionariedade daqueles que foram legitimamente eleitos para tomarem decisões políticas, pela discricionariedade dos magistrados. Ao contrário, afirma que nenhum intérprete está autorizado a realizar interpretações discricionárias, pois se as decisões judiciais que se baseiam na interpretação das leis pudessem ser feitas de forma discricionária, não haveria a necessidade da existência de leis.

Acaba por violar os princípios basilares do constitucionalismo e do Estado Democrático de Direito a tomada de decisões discricionárias, pois se baseiam em valores subjetivos, e não democráticos. Portanto, ao magistrado, cabe ater-se aos limites que o texto legal estabelece (DWORKIN, 2003).

Através de mecanismos democráticos, a Constituição deve garantir o pluralismo político, trazendo a possibilidade da participação popular representativa para legitimar o poder e as decisões dele emanadas (BARROSO, 2007).

A partir do exposto, buscar-se-á verificar se a decisão do Supremo Tribunal Federal em relação ao aborto em caso de gestação de feto anencéfalo respeitou os princípios do Estado Democrático de Direito ou se acabou adentrando na esfera da discricionariedade.

Manifestou-se o Supremo Tribunal Federal, por maioria, para declarar a inconstitucionalidade da interpretação de que a interrupção da gravidez de feto anencéfalo é conduta tipificada nos artigos 124, 126 e 128, I e II do Código Penal.

O Supremo Tribunal Federal assumiu um caráter políticoconstitucional na permissão de realizar abortos em fetos anencéfalos, que ficou representada pela escolha ética que cada um de seus membros fez dentro da crença de ser a melhor resposta para a situação em 
análise, demonstrando uma das mazelas do sistema positivista, ou seja, a multiplicidade de resposta (STRECK, 2006). O caráter extremamente político do julgamento é extraído da imprevisibilidade da decisão a ser tomada, pois se a questão fosse considerada de forma técnica, a resposta seria extraída dos instrumentos hermenêuticos constitucionais.

Segundo a visão frente ao Estado Democrático de Direito, percebe-se que houve uma ilegitimidade do Supremo Tribunal Federal para tomar essa decisão política, pois assumiu a responsabilidade de deliberações políticas ou éticas que afetam a sociedade como um todo, mas a controvérsia está no fato de que não foram eleitos pelo povo para atuar nesxe papel, cabendo como função constitucional objetiva dos tribunais a solução de litígios em questões jurídicas e não políticas. Mas isso não quer dizer que precisem se limitar a mera aplicação das normas, e sim, essencialmente, na sua interpretação (QUEIROS, 2008).

Capelletti (1993, p. 74) afirma que "o juiz ruim agiria com as formas e as modalidades do legislador, pois se assim agisse deixaria simplesmente se ser juiz", pois os magistrados também são chamados a interpretar e esclarecer o Direito, mas não a legislar.

Percebe-se que o caso em concreto deveria ter sido objeto de referendo ${ }^{3}$ para conseguir, de forma democrática e dentro da perspectiva do Estado Democrático de Direito, legitimar as possíveis diretrizes para a situação apontada.

\section{A legitimação do direito pelo Supremo Tribunal Federal e a teoria procedimentalista de Habermas}

Através de procedimentos democráticos participativos e da busca do controle e condicionamento do poder pelo Estado é que Habermas defende a construção de sistemas jurídicos, por deslocar o foco da

Referendo é convocado depois da edição da norma, devendo o povo ratificá-la ou não. 
legitimidade do sistema jurídico para o próprio processo, desde a elaboração até as decisões finais (HABERMAS, 2004).

Propõe Habermas (2004) um modelo de Estado Democrático de Direito, ou seja, os Tribunais Constitucionais, dentro de um modelo de democracia que tem como base procedimentos democráticos de opinião e vontade, exigem uma identidade política baseada em uma nação de cidadãos, visando proteger um processo de criação democrático do Direito, garantindo que a cidadania disponha de meios necessários e suficientes para entender seus problemas e buscar a forma de solucionálos.

Perante a visão habermasiana, a atuação dos Tribunais Constitucionais na tomada de decisões complexas como a que se apresenta sobre o aborto na gestação de fetos anencéfalos, que são de cunho eminentemente político-constitucional, acaba por enfraquecer a cidadania, a democracia e o pluralismo político, e, consequentemente, tais decisões estariam desprovidas da indispensável racionalidade argumentativa a que se refere Habermas (CRUZ, 2006).

Luhmann (1980) afirma que, em questões polêmicas, não se deve ter a interferência política do Poder Judiciário, devendo ser submetidas a debate nacional, pois demandam de uma escolha política, pelo fato que elas, em sua maioria, contêm questões morais e éticas; caso contrário, afastariam a possibilidade de opinião pública (GESTA LEAL, 2006; BONAVIDES, 2003).

Uma sociedade justa deve proporcionar direitos neutros aos seus cidadãos, para que possam buscar as próprias concepções de bem comum (RAWLS, 2008).

Os tribunais são "o fórum da razão pública", pois os magistrados possuem duas tarefas: usar a ordem jurídico-constitucional para solucionar os conflitos e produzir um discurso para legitimar sentimentos sobre a legislação (RAWLS, 1993).

Nessa perspectiva, a função dos tribunais seria somente para solução de questões jurídicas, e não de natureza política, pois extrapola 
o âmbito de sua atuação. Para a resolução dos litígios, utiliza-se como norte o que já está previamente estabelecido pelo legislador político democrático, ou seja, a coerência entre os significados linguísticos textuais dos preceitos jurídicos e a correção da decisão no caso concreto (QUEIROS, 2008). Mas essa atuação consiste em elaborar, conforme a ordem jurídica vigente, uma interpretação, e não uma mera aplicação ou execução do que está previsto na lei.

Distinguindo o magistrado e o legislador, pode-se dizer que: o magistrado tem a obrigação de utilizar as premissas jurídicas para fundamentar suas decisões de forma coerente, enquanto o legislador toma suas decisões de forma política, sem necessariamente ter preocupações com a coerência.

Passa-se a verificar, dentro dos parâmetros adotados pelo filósofo alemão Habermas e sua teoria procedimentalista, se houve, de forma legítima, a efetivação de uma jurisdição constitucional aberta e democrática na questão sobre o aborto em gestação de fetos anencéfalos pelo Supremo Tribunal Federal.

Primeiramente, cabe ressaltar que o referido caso não pode ser resolvido apenas com argumentos técnico-jurídicos, pois demandam posicionamentos argumentativos, éticos e morais, típicos de decisões políticas pelo caráter valorativo.

Segundo Habermas (2004), não cabe ao Supremo Tribunal Federal adotar uma solução técnica para resolver o conflito, pois é de caráter político, devendo buscar formas de garantir aos cidadãos a busca pela solução.

A decisão política adotada pelos ministros do Supremo Tribunal Federal acabou por afastar a oportunidade de manifestação da opinião pública sobre o assunto, o que, segundo Habermas (2004), acaba enfraquecendo a cidadania e a própria democracia, desvirtuando o processo e a vontade do Poder Legislativo, eleito para demandar sobre essas decisões políticas. 


\section{A decisão do Supremo Tribunal Federal frente à interrupção da gestação de fetos anencéfalos e a construção da resposta correta}

Contestando a teoria procedimentalista de Habermas, Streck (2006) afirma que elas procuram colocar no procedimento o modo ideal de operar a democracia, através de uma universalização aplicativa, trazendo à baila o fato de que não respondem às questões relacionadas. Pode-se citar como exemplo: a falta de vagas nas escolas; o fornecimento de remédios para os doentes crônicos; a falta de vagas em hospitais, que acabam sendo enfrentadas em ações no Judiciário (ações civis públicas, mandados de segurança) etc.

Essa superação de modelos já realizados (procedimentalistas) da teoria de Habermas é fundamental nas democracias em que os principais problemas de exclusão social e de direitos fundamentais já foram resolvidos, pressupondo sociedades com um grau elevado de emancipação social, com autonomia de seus indivíduos (STRECK, 2006).

Diante da crise de efetividade da Constituição e da indeterminabilidade do Direito, Streck (2006) afirma que em uma sociedade como a brasileira, carente de realização dos direitos, verifica-se a importância da discussão acerca da possibilidade de se alcançar condições de interpretação para se chegar a uma resposta constitucionalmente adequada, denominada pelo autor de "resposta correta".

Percebe-se que o Direito está assumindo cada vez mais o papel de transformador da sociedade, compreendendo-se, dessa forma, a posição adotada pelo autor e verificando que a Constituição, dentro do Estado Democrático de Direito, assumiu importante função dentro da estrutura político-social, qual seja: condicionar a legislação, a ação dos agentes públicos, a jurisprudência e as relações sociais.

O desenvolvimento de mecanismos que busquem efetivar direitos e evitar decisões arbitrárias, buscando uma resposta correta, é a grande discussão hermenêutica encontrada nesse caso. 
Posiciona-se Streck (2006) através da aplicação das teorias materiais-substanciais sobre o papel da Constituição, por entender que elas reforçam a Lei Fundamental como norma ou força normativa, ao evidenciarem o seu conteúdo compromissório a partir da concepção dos direitos fundamentais como valores a serem concretizados.

Encontra-se aqui o problema da legitimidade do Poder Judiciário perante a inércia injustificável dos outros poderes na efetivação dos direitos fundamentais, e por isso a teoria procedimentalista de Habermas, que limita o Judiciário a preocupar-se com a preservação dos procedimentos democráticos formadores da vontade política, não pode prevalecer no Brasil, país extremamente carente na efetivação dos seus direitos constitucionais, pois grande parte da população brasileira seria afastada das proteções previstas na Constituição, e, tratando-se de Brasil, estas são extremamente necessárias diante das diversas dificuldades vividas pelos brasileiros.

Dentro dos direitos fundamentais, a proteção protetiva é obrigação da jurisdição constitucional, defendida por Sarlet (2005), pois cabe ao Judiciário conceder aos direitos fundamentais a maior eficácia possível dentro do sistema jurídico.

O próprio texto constitucional, ${ }^{4}$ na busca da redução das desigualdades, abarca a necessidade da posição interventiva da jurisdição constitucional para procurar reduzir as desigualdades, mas sem ativismos judiciais. Seus objetivos: erradicação da pobreza e da marginalização, redução de desigualdades sociais e regionais, vedação de qualquer lesão ou ameaça a direito que seja excluída da apreciação do Poder Judiciário. Dentro dos remédios constitucionais: o mandado de segurança coletivo, o mandado de injunção ${ }^{5}$ e a própria ação direita de

"Art. $3^{\circ}$, III - Constituem objetivos fundamentais da República Federativa do Brasil: erradicar a pobreza e a marginalização e reduzir as desigualdades sociais e regionais." (BRASIL, 2012, p. 2). "Art. $5^{\circ}, \mathrm{LXXI}$-Conceder-se-á mandado de injunção sempre que a falta de norma regulamentadora torne inviável o exercício dos direitos e liberdades constitucionais e das prerrogativas inerentes à nacionalidade, á soberania e à cidadania." (BRASIL, 2012, p. 12). 
constitucionalidade por omissão ${ }^{6}$ em casos de falta de uma norma que regulamente a efetivação dos direitos pré-estabelecidos na Constituição Federal.

Sobre a atuação da política, a Constituição Federal reportase da seguinte forma: soberania, cidadania, dignidade da pessoa humana, valores sociais do trabalho e da livre iniciativa (art. $1^{\circ}, \mathrm{CF} / 88$ ). Também se refere aos objetivos do país, que se encontra na construção de uma sociedade livre, justa e solidária, através da garantia do desenvolvimento nacional e a promoção do bem de todos, sem qualquer tipo de preconceito ou qualquer outra forma de discriminação (art. $3^{\circ}$, $\mathrm{CF} / 88$ ), mostrando que nossa ordem jurídica fundamental se contrapõe à tese procedimentalista de Habermas, pois estabelece as condições de mudança social pelo Direito.

Para o Brasil, é necessário outro tipo de desenvolvimento, com atuação interventiva da jurisdição constitucional, ou seja, de uma teoria da Constituição que responda às suas necessidades. Portanto, buscamse ensinamentos do filósofo Heidegger (2006) para abarcar a discussão sobre a possibilidade de se alcançar condições de interpretação capaz de garantir a resposta adequada constitucionalmente. Ele afirma que a hermenêutica deve descobrir no próprio ser humano a ideia de compreensão.

Streck (2006) salienta que não há grau zero na compreensão, pois é impraticável estabelecer condições ideais de fala para alcançar um resultado a partir de uma imparcialidade proporcionada por um princípio. É que cada interlocutor sempre virá de um lugar de compreensão, ou seja, terá uma pré-compreensão sobre o objeto de estudo. Por isso, na formulação do juízo de validade do caso concreto, já estará presente a dimensão estruturante, pré-concebida ou pré-compreendida, pois, diante dos procedimentos, sempre chegamos com elementos e valores

6 "Art. 103, $\S 2^{\circ}$ - Declarada a inconstitucionalidade por omissão de medida para tornar efetiva norma constitucional, será dada ciência ao Poder competente para a adoção das providências necessárias e, em se tratando de órgão administrativo, para fazê-lo em trinta dias." (BRASIL, 2012, p. 91). 
anteriores a eles que são impossíveis de ser eliminados. Percebese, dessa forma, a inviabilidade dos discursos prévios de justificação dos processualistas, pois a resposta correta somente poderá advir de uma situação concreta, a qual servirá de parâmetro para a resposta adequada à Constituição.

A norma, então, será sempre o resultado da interpretação do texto, pois este não é somente um enunciado linguístico, mas o sentido que será dado ao caso concreto. É chamada por Streck (2006) de síntese hermenêutica, "que tem na diferença ontológica a sua condição de possibilidade", não podendo ser entendida como ativismo judicial ou jurisprudência dos valores, pois a base da chamada Crítica Hermenêutica do Direito ${ }^{7}$, construída por Streck (2006), é a filosofia hermenêutica e a hermenêutica filosófica. Nesse viés, ocorre a mudança de paradigma, e a linguagem deixa de ser um terceiro fator que se interpõe entre um sujeito e um objeto, passando a ser condição de possibilidade, uma vez que o processo interpretativo passa a ser produtivo.

Portanto, verifica-se que, na hermenêutica filosófica, interpretar o texto passa a ser sua aplicação, pois ele sempre se referirá a algum fato concreto, mas, como diz Streck (2006), para que isso ocorra, deve haver certo grau de dirigismo constitucional e a exigência da intervenção jurisdicional constitucional, em que essa sistemática terá como objetivo vedar respostas diferentes, fechando a interpretação.

Os princípios acabaram por superar a abstração da regra para evitar a discricionariedade judicial, sendo utilizados para encontrar as respostas corretas para cada caso em concreto, pois o Direito exposto como um sistema de regras (positivismo) que busca prever situações abstratas acabou excluindo de sua abrangência os casos fáticos, deixando-os sem respostas, por não ter previsão legal.

Se os magistrados interpretassem as normas subjetivamente aos casos concretos, haveria discricionariedade. Streck (2006) afirma que

7 Ou Nova Crítica do Direito. 
há um acontecer que aproxima a regra do princípio em duas dimensões, a partir de uma anterioridade, isto é, a condição de possibilidade da interpretação da regra é a existência do princípio instituidor; sendo assim, a regra está subsumida no princípio. Nos casos simples, a regra apenas encobre o princípio, porque consegue se dar no nível da pura objetivação. Contudo, diante de casos em que a objetivação é insuficiente, causada pela interpretação da regra, surge a necessidade do uso dos princípios. O princípio é o elemento instituidor, o elemento que existencializa a regra que ele instituiu. Mas está encoberto. Assim, é impossível interpretar uma regra sem levar em conta o seu princípio instituidor. (STRECK, 2006).

Expõe Gadamer (2005) que é a explicitação do compreendido que terá o papel de mostrar o lado epistemológico da hermenêutica, e não a sua simples aplicação que deixará de lado as arbitrariedades.

Afirma Streck (2006) que interpretar é compreender, e compreender é aplicar. Não se interpreta para compreender, mas se compreende para interpretar, formando-se um círculo hermenêutico (o todo deve ser entendido pela parte e a parte só adquire sentido pelo todo). A interpretação é a explicitação do compreendido nos casos em concreto.

É através da decisão do caso em concreto que se obterá a resposta correta constitucionalmente, e a objetividade interpretativa ocorrerá através dos princípios que fecham a interpretação, entretanto, essa resposta deverá ser justificada racional e adequadamente.

Com o aprofundado estudo constitucional se obterá a resposta correta para cada caso em concreto e os princípios irão sustentar e complementar as regras insuficientes, pois para cada regra existe um princípio constitucional, obtendo-se coerência e integridade do Direito, acabando por afastar a subjetividade dos magistrados nas suas decisões, limitando-os à observância e aplicação de valores materiais e princípios previstos na Constituição Federal, chegando-se à resposta correta constitucionalmente. 
Após o exposto, e baseada em fundamentos sustentadores da Crítica Hermenêutica do Direito, ou Nova Crítica do Direito, construída pelo Dr. Lenio Streck, que tem como base filosófica hermenêutica a própria hermenêutica filosófica, verificar-se-á a decisão (solução) apresentada pelo Supremo Tribunal Federal ${ }^{8}$ frente à interrupção da gravidez de feto anencéfalo, buscando verificar, dentro da teoria desenvolvida pelo Dr. Lenio Streck, se a Corte chegou à resposta correta constitucionalmente.

Primeiramente, o Supremo Tribunal Federal tinha legitimidade para buscar a solução ao caso, frente à omissão dos demais poderes sobre o referido assunto, tendo que intervir para garantir os direitos fundamentais, porque o debate envolvia direitos como: proteção à vida, liberdade, autonomia da vontade e dignidade da pessoa humana, assumindo o estudo para aplicação, interpretação e integração, de forma a conceder às normas de direitos fundamentais envolvidas a maior eficácia possível no âmbito do sistema jurídico brasileiro, buscando utilizar argumentos racionais e adequados aos princípios constitucionais para poder obter a resposta correta.

A grande discussão encontrava-se no fato de a ocorrência da interrupção da gravidez de fetos anencéfalos se configurar ou não como crime de aborto previsto pelo Código Penal, baseando-se no princípio da dignidade da pessoa humana, na liberdade, no direito à vida, por ser uma gestação perigosa para a gestante, bem como na autonomia da vontade para a realização deste aborto (fetos anencéfalos), sem punições para sua realização.

Cabe salientar que a anencefalia é uma doença congênita letal que pressupõe ausência parcial ou total do cérebro, para a qual não há cura e tampouco possibilidade de desenvolvimento da massa encefálica em momento posterior. $O$ feto anencéfalo é um natimorto com possibilidade quase nula de sobreviver. Criminalizar o aborto de feto anencéfalo não é cuidar de vida, de vida em potencial, mas cuidar de morte segura,

\footnotetext{
8 Ação Direta de Inconstitucionalidade (ADI n 3.510) que atacou a constitucionalidade do art. $5^{\circ} \mathrm{e}$ parágrafos da Lei $n^{\circ} 11.105 / 2005$, por afronta ao art. $1^{\circ}$, III da Carta Magna.
} 
impondo (desnecessariamente) graves riscos para a saúde da mãe e consequências psicológicas severas.

O caso concreto deve ser resolvido individualmente, observando suas peculiaridades, sem a criação de uma resposta abstrata para ser aplicada em outras, ou todas, as situações sobre o mesmo assunto. É nesse viés que se chama de resposta correta, pois será a solução mais adequada segundo os preceitos constitucionais para cada caso específico.

Como a grande discussão girava em torno da possibilidade de vida do feto anencéfalo, o Supremo Tribunal Federal realizou uma audiência pública anteriormente ao julgamento, da qual participaram vários especialistas, a fim de conseguir dados e explicações suficientes para que pudessem tomar a decisão.

Após isso, os únicos votos contrários foram do Ministro Ricardo Levandowsky e do Presidente do Tribunal, Cézar Peluso, tornando, dessa maneira, procedente a Arguição de Descumprimento de Preceito Fundamental (ADPF) proposta pela Confederação Nacional dos Trabalhadores na Saúde (CNTS) contra os artigos 124, 126, caput e 128, I e II do Código Penal ${ }^{9}$.

O Ministro Luiz Fux argumentou que o Brasil é um país que se encontra na lista de mais ocorrências de fetos anencéfalos, com uma média de 8,6 fetos anencéfalos para cada 10 mil nascimentos com vida. Além disto, poucos são os casos em que o infante sobrevive por um tempo considerável após o nascimento. Dados mostram que $94 \%$ dos recém-nascidos anencéfalos faleceram nas 24 horas após o nascimento.

Destacou, ainda, que, hodiernamente, existem exames seguros que detectam a existência da anencefalia durante a gestação, no entanto, essa enfermidade é irreversível e os estudos apontam ser uma anomalia fatal para o feto. Além disso, o ministro discorreu acerca da necessidade de proteção da saúde física e psíquica da gestante, haja

9 ADPF 54/DF, rel. Marco Aurélio. 
vista a existência dos graves riscos à sua vida, devendo-se conferir a possibilidade de interrupção da gestação.

O Ministro Luiz Fux argumentou que seria prematuro se o STF solucionasse como se fosse legislador os inúmeros debates que ocorrem na sociedade pluralista brasileira, mas que o art. 128 do Código Penal deve ser interpretado consoante as novas necessidades científicas e sociais, porquanto à época da criação do Código Penal inexistiam os métodos de diagnóstico de anencefalia. Portanto, a penalização de uma gestante de feto anencefálico não é necessária, pois, além de ser uma sanção desproporcional, inafasta a dignidade da gestante. A decisão destaca, ainda, que a decisão da Suprema Corte não impõe a realização de aborto do feto anencefálico, mas não pune as gestantes que o realizarem. Destarte, decidiu-se por conferir a interpretação ao art. 128 do Código Penal para não reconhecer o crime de aborto nas hipóteses de interrupção voluntária da gravidez de feto anencefálico.

O Ministro Marco Aurélio afirmou em um primeiro momento que a ADPF $n^{\circ} 54$ é uma das mais importantes ações analisadas pelo Supremo Tribunal Federal, devido à intensidade dos argumentos das partes e ao envolvimento da sociedade.

A relevância do assunto é pelo fato de que o Brasil é o quarto país do mundo em casos de fetos anencéfalos. Ademais, de um lado, tem-se o confronto dos interesses da mulher que quer o respeito da sua dignidade; de outro, a defesa da sociedade de proteção daqueles que estão para nascer e daqueles que nasceram com anencefalia. Desse modo, a temática abrange certos direitos, como: vida, liberdade, autodeterminação, saúde etc. Contudo, salientou que não há uma colisão entre direitos fundamentais, somente um conflito aparente, porque se o feto não possui cérebro, não terá potencialidade de vida, logo, o anencéfalo nunca será uma pessoa, pois o fato de respirar e seu coração bater não altera essa conclusão. Na ADPF, não se discute a descriminalização do aborto. Segundo Marco Aurélio, "aborto é crime contra a vida. Tutela-se a vida em potencial. No caso do anencéfalo, repito, não existe vida possível”. Lembrando que, na época do Código 
Penal, década de 1940, o legislador estabeleceu que o aborto em gestação oriunda de estupro não seria crime, situação em que o feto é plenamente viável (BRASIL. STF, 2012d).

Por conseguinte, o Ministro Marco Aurélio julgou procedente o pedido para declarar a inconstitucionalidade da interpretação de que a interrupção da gravidez de feto anencéfalo é conduta tipificada nos artigos 124, 126, 128, incisos I e II, do Código Penal brasileiro.

A Ministra Rosa Weber também julgou pela procedência do pedido inicial, com o fundamento de que não é o direito à vida que está a se questionar, haja vista que o Conselho Federal de Medicina afirma que o feto não terá atividade cerebral, ou seja, não irá ter capacidade psíquica e física inata ao ser humano.

Além disso, ressaltou que a genitora tem o direito de escolha entre a interrupção da gestação do feto que ou nascerá morto ou morrerá em pouco tempo após o parto, destacando o direito da autonomia da gestante e excluindo a interpretação segundo a qual a interrupção ou antecipação do parto em caso de feto anencéfalo configura crime de aborto $^{10}$.

O Ministro Ayres Britto também defendeu a possibilidade de a mulher interromper a gravidez sem que tal atitude seja criminalizada, pois, segundo ele, a gravidez é destinada à vida, e não à morte. Afirmou que a decisão cabe à mulher sobre a interrupção ou não da gestação de feto anencéfalo, a qual é ditada pelo mais forte e sábio dos amores: o amor materno. Ele frisou, ainda, que se a mulher optar por levar às últimas consequências, ninguém poderá proibi-la.

A procedência do pedido na ADPF n 54 também foi realizada pela Ministra Cármen Lúcia, a qual ressaltou que o Supremo Tribunal Federal não está permitindo o aborto no país, tampouco a possibilidade de aborto

10 No mesmo sentido é o voto do Ministro Joaquim Barbosa. 
devido a alguma deformação, e sim a interpretação a ser realizada dos dispositivos do Código Penal.

Já o Ministro Gilmar Mendes aduziu que a situação de interrupção da gravidez de feto anencéfalo trata-se de uma hipótese de aborto, mas a compreende como causa excludente de ilicitude, já que a gestação torna-se perigosa para a saúde da gestante.

Ressaltou o Ministro Celso de Mello, que uma vez sendo diagnosticada a anencefalia por médico habilitado, é reconhecido à genitora a realização do procedimento sem necessidade de autorização judicial, e também votou pela procedência da ação. Celso de Mello reconheceu o direito da gestante de se submeter ao diagnóstico antes mesmo de autorização judicial ou permissão outorgada por qualquer outro órgão do Estado. Relatou que na Assembleia Nacional Constituinte foram apresentadas diversas emendas sobre a definição do início da vida e que a Constituição não o define. Para o ministro, o feto anencéfalo não é um ser humano vivo porque não tem cérebro e não irá desenvolver atividade cerebral: "se não há vida a ser protegida, não há tipicidade". (BRASIL. STF, 2012a).

O Ministro Ricardo Lewandowski, em seu voto, destacou que o Supremo Tribunal Federal somente pode exercer o papel de legislador negativo, ou seja, somente pode extirpar do ordenamento as normas incompatíveis com a Constituição. Isso significa que os integrantes do Poder Judiciário não podem promover inovações jurídicas como se parlamentares fossem.

Já no que concerne ao tema em questão, afirma que o aborto é demasiadamente controvertido em muitos países. Mas tanto aqueles que são favoráveis à interrupção da gravidez quanto os contrários invocam o princípio da dignidade da pessoa humana. Ademais, salientou que a temática possui complexidade não somente sob o viés jurídico, mas também sob o viés ético e científico.

O ministro destacou a opinião proferida pelo Doutor Rodolfo Acatuassú Nunes, professor adjunto do Departamento de Cirurgia Geral 
da Faculdade de Medicina da UERJ, para quem, embora a anencefalia seja uma doença congênita letal, não é a única, haja vista a existência de acardia, agenedia renal, hipoplasia pulmonar, atrofia muscular espinhal, ostogênese imperfeita letal, entre outras, e que, em razão disso, estarse-ia abrindo portas para a interrupção da gestação de outros embriões que sofrem destas ou de outras doenças.

O ministro também ressaltou a preocupação com o sofrimento dos fetos anencéfalos, pois, apesar de não possuírem um sistema nervoso central completo, acabam por sentir dor. No dispositivo, o Ministro Lewandowski aduziu que a autora pretendeu que o Supremo Tribunal Federal elaborasse norma abstrata autorizadora do aborto dito terapêutico nas situações de anencefalia, fato este que seria da competência do Congresso Nacional, criticando o ativismo judicial pelo risco e usurpação de poderes atribuídos constitucionalmente aos integrantes do Congresso Nacional: "Não é dado aos integrantes do Judiciário, que carecem de unção legitimadora do voto popular, promover inovações no ordenamento normativo como se fossem parlamentares eleitos. Por tal motivo, julgou improcedente o pedido." (BRASIL, online, 2012b).

Por fim, o Ministro Cezar Peluso também votou pela improcedência da ADPF, sustentando que, se o Congresso Nacional não tipificou no artigo 124 a hipótese de anencéfalos, o STF não está legitimado a criar essa situação. Manifestou improcedência do pedido alegando que o feto anencéfalo é portador de vida e, portanto, tem os seus direitos tutelados. Para o ministro, morre apenas aquele que tem vida, sendo o aborto de anencéfalo uma espécie de discriminação que reduz o feto à condição de lixo. Nas palavras de Peluso, significaria "a absurda defesa e absolvição da superioridade de uns sobre outros". No encerramento de seu voto, o presidente criticou o ativismo judicial, ressaltando que não cabe ao Supremo Tribunal Federal atuar como legislador: "não temos legitimidade para criar judicialmente esta hipótese legal, [...] é o Congresso Nacional que não quer assumir essa responsabilidade e tem motivos para fazê-lo" (BRASIL. STF, 2012c). 
Cabe salientar, frente à posição dos ministros do Supremo Tribunal Federal, que não se pode usar os princípios para possibilitar diferentes interpretações - como eles reportam-se ao da dignidade da pessoa humana -, pois objetivam impedir a proliferação de respostas diferentes, fechando a interpretação.

Os ministros se utilizam de um princípio constitucional para ampliar a interpretação sobre a aplicação da norma constitucional, defendendo a dignidade humana, com ampliação de significados, em contradição argumentativa. Posicionamento que não se compatibiliza com a Crítica Hermenêutica do Direito, pois esta tem o papel de fechar o processo de interpretação das normas, evitando decisões discricionárias.

Nota-se que a dignidade humana (princípio) e o direito à vida (regra) começam com o nascimento e, por consequência dessa interpretação, não se poderia punir situações como o aborto, ou então se admite que a vida e a dignidade da pessoa humana existem desde a concepção, segundo afirma o Código Civil brasileiro, tendo, dessa forma, a justificativa constitucional para a criminalização do aborto e a proteção dos fetos anencéfalos.

Considera-se, através da Crítica Hermenêutica do Direito ou da Nova Crítica do Direito (teoria esta criada por Streck), que a decisão tomada pelo Supremo Tribunal Federal, permitindo o aborto em gestação de fetos anencéfalos, não é a resposta correta e tampouco a constitucionalmente adequada para o caso em concreto, pois abriu a aplicação do princípio constitucional da dignidade humana para ser aplicado dentro do direito fundamental à vida, criando várias respostas e, consequentemente, oportunidade para a discricionariedade.

Percebe-se, quanto aos limites da interpretação dos princípios constitucionais, um grande desrespeito, pois o julgamento focou em valores individuais de cada um dos ministros do Supremo Tribunal Federal, relatados em seus votos, do que na aplicação da Constituição Federal para a resolução do caso em concreto, obtendo-se, infelizmente, na presente decisão a presença da discricionariedade. 


\section{Conclusão}

$\mathrm{Na}$ atualidade, com a evolução da sociedade, também houve uma complexidade de seus problemas e fenômenos jurídicos, dentre eles, o aspecto normativo, a dinâmica sociocultural, pautada, sobretudo, no avanço e suas repercussões na esfera médica, suscitando questões controvérsias, alcançando um grau de especialização que o Poder Legislativo não conseguiu prever, acompanhar ou responder definitivamente ao caso em concreto, gerando uma crise no Direito positivo. Ocorrendo a busca para a solução no Poder Judiciário, passou este a assumir um papel mais ativista nesses conflitos, como ocorreu com a permissão para a realização de aborto em gestação de fetos anencéfalos, provocando a jurisdição constitucional exercida pelo Supremo Tribunal Federal.

Sustenta Habermas (2003a) que o problema supracitado revela uma escolha mais ética e política do que uma análise técnico-jurídica em suas teses, trazendo para os ministros do Supremo Tribunal Federal a responsabilidade de decidirem determinada situação para a qual não foram eleitos democraticamente, causando o enfraquecimento do Poder Legislativo.

Percebe-se que a decisão do Supremo Tribunal Federal foi realizada sem a participação da população - através de seus representantes, ou por consulta popular -, violando o princípio defendido por Habermas segundo o qual a jurisdição constitucional deve ser realizada de forma aberta e democrática.

Em oposição à teoria de Habermas encontra-se a Teoria Crítica Hermenêutica do Direito, desenvolvida pelo Dr. Lenio Streck, na qual se percebe que o Supremo Tribunal Federal tem legitimidade para responder ao caso, na garantia da efetivação dos direitos fundamentais (o direito à vida, o princípio da dignidade humana e a autonomia da vontade), trazidos à baila para conseguir uma maior eficácia possível através de argumentos racionais e adequados aos princípios constitucionais: a resposta correta frente à Constituição Federal. 
Nota-se que o Supremo Tribunal Federal não respeitou as bases teóricas desenvolvidas por Streck, pois procurou dar uma interpretação aberta à aplicação do princípio da dignidade da pessoa humana para o direito fundamento à vida, abrangendo o princípio nas leis infraconstitucionais e, consequentemente, obtendo respostas discricionárias.

A instabilidade e contrariedade das decisões judiciais e dos múltiplos entendimentos giram em torno da incompreensão adequada sobre a interpretação dos princípios constitucionais, que devem fechar a interpretação das regras contidas na Constituição Federal, e não ampliá-la, pois acabam afastando o conteúdo constitucional da decisão.

\section{Referências}

BAJER, Paula. Sobre a importância do poder judiciário na configuração do sistema de separação dos poderes instaurado no Brasil após a constituição de 1988. Revista de Direito Constitucional e Internacional, São Paulo, v. 8, n. 30, p.240-258, jan./mar. 2000.

BARRETO, Vicente. Direitos humanos e sociedades multiculturais. In: ROCHA, Leonel Severo; STRECK, Lênio. Anuário do Programa de Pós-Graduação em Direito: Mestrado e Doutorado. São Leopoldo: Unisinos, 2003. p. 459-483.

BARROSO, Luís Roberto. Em defesa da vida digna: constitucionalidade e legitimidade das pesquisas com células-tronco embrionárias. In: SARMENTO, Daniel; PIOVESAN, Flávia (Coord.). Nos limites da vida. Rio de Janeiro: Lumen Júris, 2007. p.241-264.

BOGOD, David. The nazi hypothermia experiments: forbidden data. Anaesthesia, London, v. 59, n. 12, p. 1.155, dez. 2004.

BONAVIDES, Paulo. Teoria da democracia participativa. 2. ed. São Paulo: Malheiros, 2003.

BRASIL. Constituição (1988). Constituição da República Federativa do Brasil. 35. ed. São Paulo: Saraiva, 2012. 
SupremoTribunalFederal. Decanovota peladescriminalização da interrupção de gravidez de feto anencefálico. 12 abr. 2012a. Disponível em: <http://www.stf.jus.br/portal/cms/verNoticiaDetalhe. asp?idConteudo=204879> . Acesso em: 10 ago. 2012.

- Interrupção de gestação de anencéfalos: ministro Lewandowski abre divergência. 11 abr. 2012b. Disponível em: <http:// www.stf.jus.br/portal/cms/verNoticiaDetalhe.asp?idConteudo=204758>. Acesso em: 15 ago. 2012.

. Ministro Cezar Peluso julga improcedente a ADPF 54. 12 abr. 2012c. Disponível em: <http://www.stf.jus.br/portal/cms/ verNoticiaDetalhe.asp?idConteudo=204881 > . Acesso em: 13 ago. 2012.

. Relator vota pela possibilidade da interrupção de gravidez de feto anencéfalo. 11 abr. 2012d. Disponível: <http://www.stf.jus.br/ portal/cms/verNoticiaDetalhe.asp?idConteudo=204680>. Acesso em: 12 ago. 2012.

CAPPELLETTI, Mauro. Juízes legisladores? Tradução Carlos Alberto Álvaro de Oliveira. Porto Alegre: Sérgio Antônio Fabris Editor, 1993.

DWORKIN, Ronald. Domínio da vida: aborto, eutanásia e liberdades individuais. São Paulo: Martins Fontes, 2003.

GADAMER, Hans-Georg. Verdade e método I: traços fundamentais de uma hermenêutica filosófica. Tradução: Flávio Paulo Meurer. 7. ed. Petrópolis: Vozes, 2005.

GESTA LEAL, Rogério. As potencialidades lesivas à democracia de uma jurisdição constitucional interventiva. Revista do Instituto de Hermenêutica Jurídica: direito, estado e democracia, Porto Alegre, n. 4, p. 353-410, 2006.

GILISSEN, John. Introdução histórica ao direito. 4. ed. Lisboa: Fundação Calouste Gulbenkian, 2003.

GOLDIM, José Roberto. Bioética e complexidade. In: MARTINS-COSTA, Judith; MÖLLER, Letícia Ludwig (Org.). Bioética e responsabilidade. Rio de Janeiro: Forense, 2009. p. 145-204. 
HABERMAS, Jürgen. Direito e democracia: entre faticidade e validade. Tradução Flávio Beno Siebeneichler. 2. ed. Rio de Janeiro: Tempo Brasileiro, 2003a. v. 1.

Sobre a legitimação pelos direitos humanos. In: MERLE, JeanCristophe; MOREIRA, Luiz (Org.). Direito e legitimidade. São Paulo: Landy, 2003b. p. 67-82.

Três modelos normativos de democracia. In: inclusão do outro. 2. ed. São Paulo: Loyola, 2004. p. 277-292.

HEIDEGGER, Martin. Ser e tempo. Tradução Márcia Sá Cavalcante Schuback. Petrópolis: Vozes, 2006.

HOBSBAWM, Eric. A era dos extremos: o breve século XX. Tradução Marcos Santarrita. São Paulo: Companhia das Letras, 2006.

JUNGES, José Roque. Bioética e os paradigmas da justiça e do cuidado. In: . Bioética hermenêutica e casuística. São Paulo: Edições Loyola, 2006.

KELSEN, Hans. Teoria pura do direito. Tradução João Baptista Machado. 4. ed. Coimbra: Armênio Amado Editor, 1976.

LARENZ, Karl. Metodologia da ciência do direito. 4. ed. Lisboa: Fundação Calouste Gulbenkian, 2005.

LUHMANN, Niklas. A legitimação pelo procedimento. Brasília: Unb, 1980.

MÖLLER, Letícia Ludwig. Esperança e responsabilidade: os rumos da bioética e do direito diante do progresso da ciência. In: MARTINS-COSTA, Judith; MÖLLER, Letícia Ludwig (Org.). Bioética e responsabilidade. Rio de Janeiro: Forense, 2009. p. 23-53.

QUEIROS, Cristina M. M. Direitos fundamentais (Teoria geral). Porto: Faculdade de Direito da Faculdade de Porto, 2008.

RAWLS, John. Political liberalism. New York: Columbia University Press, 1993. 
. Uma teoria da justiça. Tradução Jussara Simões. São Paulo: Martins Fontes, 2008.

SARLET, Ingo Wolfgang. A eficácia dos direitos fundamentais. Porto Alegre: Livraria do Advogado, 2005.

SOUZA CRUZ, Álvaro. Habermas e o direito brasileiro. Rio de Janeiro: Lumen luris, 2006.

STRECK, Lenio. Verdade e consenso: constituição, hermenêutica e teorias discursivas. Rio de Janeiro: Lumen luris, 2006.

ZAGREBELSKY, Gustavo. Historia y constitución. Torino: Trotta, 2005.

Recebido em: 21/03/13

Aprovado em: 24/11/13 